\title{
Child Sexual Abuse and Eating Disorders
}

\author{
Jarząbek-Bielecka $\mathbf{G}^{\mathbf{1}}$, Mizgier $\mathbf{M}^{2 *}$ and Kędzia $\mathbf{W}^{\mathbf{1}}$ \\ ${ }^{1}$ Department of Gynecology, Poznań University of Medical \\ Sciences, Poland \\ ${ }^{2}$ Department of Morphological and Health Sciences, \\ University School of Physical Education in Poznan, \\ Poland \\ *Corresponding author: Mizgier M, Department of \\ Morphological and Health Sciences, Dietetic Division, \\ Faculty of Physical Culture in Gorzów Wlkp, Poznań \\ University School of Physical Education, Poland
}

Received: September 06, 2018; Accepted: October 03, 2018; Published: October 10, 2018

\section{Abstract}

Adolescents and children with eating problems often suffer from symp of post-traumatic stress disorder without realizing that its origins lie in sexual abuse.

Child Sexual Abuse (CSA) is defined as the use of children for sexual stimulation of adults or older adolescents. A wide range of contact and noncontact activities is included in CSA. Contact abuse can include any activity from sexualized kissing, fondling, masturbation, digital or object penetration of the vagina or anus, to genital, oral-genital, and anal-genital contacts. Noncontact activities include inappropriate observation of child (e.g. during bath or in a rest room), exhibitionism, pornography and involvement of child in prostitution

Eating disorders are often a way to manage trauma in order to reduce suffering, relieve stress and tension, block unwanted feelings and emotions, attempt to recover shattered self-esteem, distract oneself away from suffering related to trauma, eliminate a sense of guilt or deny own sexuality, a way to express hatred to own body. Many people with eating disorders feel guilty about the sexual abuse in their childhoods, believing they could have prevented it but chose not to because of some defect in themselves.

Keywords: Sexual Violence; Eating Disorders; Anorexia; Bulimia

\section{Introduction}

Adolescents and children with eating problems often suffer from symptoms of post-traumatic stress disorder without realizing that its origins lie in sexual abuse. According to the study, some victims of child sexual abuse may develop eating disorders of various forms and intensities. Eating disorders are often a way to manage trauma in order to reduce suffering, relieve stress and tension, block unwanted feelings and emotions, attempt to recover shattered self-esteem, distract oneself away from suffering related to trauma, eliminate a sense of guilt or deny own sexuality, a way to express hatred to own body [1]. Many people with eating disorders feel guilty about the sexual abuse in their childhoods, believing they could have prevented it but chose not to because of some defect in themselves [2].

Changes in children behavior, including eating disorders may be related to other child issues, although they should always be seriously considered in the context of sexual abuse.

As adults, people who were sexually abused as a child suffer from depressions, neurosis, psychotic disorders, sexual obsessions, and eating disorders as mentioned before.

According to doctors, pedagogues, and psychologists, the key element as regards sexual violence towards children is fast and reliable identification of the crime, which facilitates commencement of therapeutic activities and legal proceedings.

From the primary care perspective, general practitioners, pediatricians, dieticians and dentists should be familiar with signs and symptoms of CSA and abnormal eating behaviors, since both phenomena can be encountered in a large number of patients. Early diagnosis increases patient's chance for recovery [1].
According to the study, some victims of child sexual abuse may develop eating disorders of various forms and intensities.

Post traumatic stress may be characterized by depression, feeling chronically "dead" inside, having recurrent anxiety or nightmares, or feeling constantly and painfully vigilant to one's surroundings [2].

A contact or interaction between a child and an adult where the child is used by the adult for sexual stimulation is sexual child abuse. Child Sexual Abuse (CSA) is defined as the use of children for sexual stimulation of adults or older adolescents. A wide range of contact and noncontact activities is included in CSA. Contact abuse can include any activity from sexualized kissing, fondling, and masturbation, digital or object penetration of the vagina or anus, to genital, oral-genital, and anal-genital contacts. Noncontact activities include inappropriate observation of child (e.g. during bath or in a rest room), exhibitionism, pornography and involvement of child in prostitution.

\section{Many authors describe psychological and behavioral symptoms of sexual violence such as:}

excessive erotic behavior of the child: provocative and seductive sexual behavior, artistic activity related to sexuality: pictures or games, engaging younger children in sexual activity not typical of their age (e.g. enactment by a kindergarten child of coitus, oral or anal contact), sexual violence towards peers, early or intensive masturbation not adequate to the current phase of psychosexual development, sexrelated language inadequate to the developmental stage.

- $\quad$ Poor mood

- Anxiety, fear (the child may be afraid of going to school, of contact with other people, of sleeping alone, etc.)
Austin J Obstet Gynecol - Volume 5 Issue 8 - 2018

Submit your Manuscript | www.austinpublishinggroup.com

Mizgier et al. (c) All rights are reserved
Citation: Jarząbek-Bielecka G, Mizgier M and Kędzia W. Child Sexual Abuse and Eating Disorders. Austin J Obstet Gynecol. 2018; 5(8): 1124 
- Strong sense of guilt, low self-esteem

- Indicating to others that there is a terrible secret

- $\quad$ Suicidal ideation

- $\quad$ Nightmares, night terror (often focusing on sexual abuse), insomnia

- Difficulties with concentration

- $\quad \mathrm{ADHD}$

- Runaways

- Secondary nocturnal

- $\quad$ Regressive behavior (thumb/dummy sucking)

- Drinking alcohol, drug abuse

- Prostitution

- $\quad$ Eating disorders

- $\quad$ Problems at school, poor relations with peers

- Psychosomatic disorders: abdominal pain, headache, nausea, vomiting without a somatic cause

Self-mutilation (this types of auto aggression are not aimed to kill oneself but to interrupt unbearable emotional suffering)

\section{A directory of possible children behavior related to sexual violence has been compiled it includes:}

- $\quad$ Sleep disorders, nightmares, and night terror

- Inexplicable occurrence of somatic disorders such as abdominal pain

- Headache, vomiting, and nausea

- Anxiety, fear, phobia

- Isolation, child shutting itself away

- $\quad$ Regressive behavior such as weepiness, clinging to parents

- Motor hyperactivity, masturbation

- Problems with learning, conflicts at school, aversion to homework

- Depression, gloom, sadness, attempted suicide

- Sudden anxiety towards a parent of a given sex

- Unexpected, sudden interest in sex, own body, and sex life and bodies of parents, other people $[4,5,6,7,8,9]$.

According to authors' observations, some victims of childhood sexual violence may develop the above-mentioned eating disorders of various forms and intensities as a kind of 'self-mutilation.' In particular in girls typical are eating disorders in the form of barophobic syndromes. Girls loss or gain weight rapidly and alarmingly and become addicted mainly to sweats (intense slimming down, it may be anorexia or more commonly bulimia). According to literature, victims of sexual violence may demonstrate various eating disorders as a way to manage trauma to reduce suffering, relieve stress and tension, block unwanted feelings and emotions, attempt to recover shattered self-esteem, distract oneself away from suffering related to trauma, eliminate a sense of guilt or deny own sexuality, a way to express hatred to own body.

Sometimes adults who visit doctors, psychologists, or dieticians in relation to eating disorders report during an in-depth history-taking that in their opinion the cause of their eating disorders lies in sexual violence experienced sometimes long ago as a child or an adolescent. As adults, people who were sexually abused as a child often suffer from depression, neurosis, psychotic disorders, sexual obsessions, and eating disorders.

Violence has long-lasting repercussions that include: anxiety, depressive disorders, psychosis, personality disorders, and eating disorders.

Eating disorders involve extreme elimination of food, a neverending diet, which gradually becomes stricter. As mentioned above, the most common types of eating disorders are anorexia nervosa and bulimia nervosa (Commonly referred to as anorexia and bulimia). Orthorexia is a slightly less common disorder.

Eating disorders disrupt the menstrual cycle and the process of maturation in girls. It is estimated that energy and nutrient values of daily diets and energy availability have an important place in the etiology of menstrual disorders. Excessive physical activity and inadequate nutrient intake (observed in eating disorders) lead to negative energy balance and stimulation of the corticotropic axis (endorphins, ACTH, cortisol) under conditions of increased stress leading to disturbances of gonadoliberin secretion. This is very important problem, because it has been also shown a significantly decreased bone density in girls suffering from amenorrhea $[5,10,11]$

The most common types of eating disorder are anorexia nervosa and bulimia nervosa (usually called simply "anorexia" and "bulimia"). They represent a very important medical (adolescent gynecology too), social and psychological problem.

The term 'anorexia' was used for the first time by an English doctor, William Gull in 1873. This disorder may also be described as fear of obesity, which leads to refusal to intake food. In the case of anorexia resulting from sexual violence, it is not about fear of obesity as was mentioned above.

Adolescence is normally characterized by: intense physical development, hormone activity, psychological changes: formation of psychosexual identity or individualization, improvement of abstract thinking, and emotional lability $[2,3,5]$.

Anorexia is influenced by individual, cultural, and family factors. Individual factors include: disrupted vision of own body, depressions, obsessions, emotional deficits, and personality disorders, and sexual violence should be considered a specific cause of anorexia.

During the initial period of the disorder, weight loss is the primary symptom. After some time, body proteins, mainly muscles, are used and then water-electrolyte and hormone imbalances occur. The body of an affected person becomes unnaturally slim, facial features become sharper, and skin is excessively dry. The body is weak, the patient often apathetic, finds it difficult to focus, cardiovascular issues occur, body temperature balance is disrupted. Girls often experience stoppage of menstrual periods, inhibited growth, and hair loss. These 
changes are accompanied by increased irritability.

It is a common belief that anorexia affects women only but there are cases of this disorder in males. Both male and female victims of sexual violence may develop eating disorders as a consequence. Sexual violence and anorexia or other eating disorders alike affect females more often $[3,4,6,7,8]$.

People with anorexia exhibit notorious in appetence and constantly count calories during meals, while at the same time striving to prepare elaborate meals for the whole family. Alienation, isolation from friends and family is typical of them. Note that it may be the primary cause, sexual violence that may cause the alienation. Anorexia is devious regardless of its underlying cause. Its initial stage remains concealed, psychosomatic fitness is unaffected for a long time, which facilitates its covert development. This results in the disorder becoming noticeable in its highly advanced stage when it is much more difficult to treat it $[3,5,6,7]$.

In adolescents who were sexually abused occurs a regression to the earlier stage of development, inhibition, anxiety, phobias, sense of guilt, shame, helplessness, sense of harm, and 'otherness', which may result in eating disorders. Victims of sexual violence may develop aggression, weepiness, rage attacks, hyperactivity, concentration issues, memory problems, and eating disorders. Such children wet the bed, mutilate themselves, and attempt suicides. They have trouble falling asleep and experience nightmares. They complain about various aches and fatigue, lose appetite or overeat (bulimia).

According to some reports, bulimic behavior in the form of binge eating followed by purging are more common in patients with eating disorders who were victims of sexual abuse $[4,5,6,7]$.

Health promotion, including sex education and formation of correct eating habits is an important element of eating disorders prevention in girls. As regards treatment, the most effective seems to be a combination of, most often outpatient, therapeutic methods. In the case of recurrence or chronic disorders, some patients require hospitalization or combined out- and inpatient treatment (individual and group therapy). The primary goal of the treatment is restoration of correct body mass or prevention of continued weight loss and damage to the body. The standard should be providing the patient with a help of therapeutic team consisting of a psychologist, psychiatrist, and other medical specialists, including a gynecologist or sexologist. The team should include a dietician as well.

During therapy, it is vital to achieve an agreement with the patient and win their trust. It often happens that antipathy or aggression towards the therapist results from the fear of talking about food or of gaining weight. It is the task of the dietician to introduce nutrition education in such a way so that the patient understands the purpose of implementation of their recommendations. At the beginning, the diet should be light, fully absorbable, low fat, and low lactose. New meals or foods or those that provoke anxiety should be introduced gradually not to cause flatulence or gas, which could result in a refusal to continue the treatment. There is no one effective method to handle patients with eating disorders. An important component of effective work of a specialist with the patient is individual approach to each case and empathic attitude that facilitates building a correct relation with the patient. In the case of minors, dialogue and education of parents is important as well $[10,12]$.

Changes in children behavior, including eating disorders may be related to other child issues, although they should always be seriously considered in the context of sexual abuse $[13,14,15,16]$.

'Concern for the child [...] is the primary and fundamental test of the relationship of one human being to another'

\section{John Paul II}

Both in gynaecology and developmental sexology this concern for the child is expressed in a special and specific way in the context of the issue of child sexual abuse. As has been emphasized many times, this issue requires a specific, emphatic and professional specialist approach [15].

As Prof. Imieliński wrote: 'A human being should have as much freedom to express and satisfy its needs as possible as long as it is not detrimental to the development of another human or the society' [16].

A type of, a particularly harmful, expression and satisfaction of own sexual needs are pedophile acts. Consequences of child sexual abuse are physical injuries and disturbed natural psychosexual development. According to authors' observations, victims of childhood sex crimes consult doctors or psychologists after various periods following the trauma. Some of them never intentionally talk to specialists and the problem is discovered by coincidence, for example during gynecological tests or dietary consultations. Eating disorders are an important interdisciplinary problem $[5,9,13,14,15,16]$.

\section{References}

1. Opydo-Szymaczek J, Jarząbek-Bielecka G, Kędzia W, Borysewicz-Lewicka M. Child sexual abuse as an etiological factor of overweight and eating disorders - considerations for primary health care providers. Ginekol Pol. 2018; 89: 48-54.

2. Murray CD, Macdonald S, Fox J. Body satisfaction, eating disorders and suicide ideation in an Internet sample of self-harmers reporting and not reporting childhood sexual abuse. Psychol Health Med. 2008; 13: 29-42

3. Jarząbek-Bielecka G, Sowińska-Przepiera E, Mizgier M, Pisarska-Krawczyk M, Kędzia W. Zaburzenia odżywiania jako skutki wykorzystywania seksualnego dzieci- aspekty seksuologiczne i endokrynologiczne. Endokr. Pediat. 2017: 16; 133-136.

4. Morse O, Shapira L. The Relationship between Sexual Abuse/Trauma and Eating Disorders. materiały ośrodka New Realities Eating Disorders Recovery Centre.

5. Jarząbek-Bielecka G, Mizgier M. Eating disorders as a problem in adolescent gynecology. Now Lek. 2009; 78: 234-236.

6. Makara-Studzińska M, Żoga J, Grzywa A. Zaburzenia odżywiania a doświadczenie wykorzystania seksualnego w dzieciństwie - przegląd badań. Postępy Psychiatrii i Neurologii. 2006; 15.

7. Clayton $\mathrm{AH}$. Wykorzystywanie seksualne i jego konsekwencje dla zdrowia psychicznego. Psychiatria po dyplomie. 2004; 1.

8. Briere J, Scott C. Assessment of Trauma Symptoms in Eating-Disordered Populations. Eating Disorders. 2007; 15: 347-358.

9. Sowińska-Przepiera E, Andrysiak-Mamos E, Jarząbek-Bielecka G, Walkowiak A, Syrenicz A. Wykorzystywanie seksualne dziewcząt aspekty medyczne, prawne i etyczne. Sexual abuse of girls aspects of medical, legal and ethical. Klin. Pediat. 22 (zesz. spec.) Algorytmy w pediatrii. 2014: 71127116.

10. Lewitt A, Brzęczek K, Krupieniacz A. Interwencje żywieniowe w leczeniu 
anoreksji - wskazówki dietetyczne. Endokrynologia otyłość i zaburzenia przemiany materii. 2008; 4:128-136

11. Łagowska K, Kapczuk K, Friebe Z, Bajerska J. Effects of dietary intervention in young female athletes with menstrual disorders. J Int Soc Sports Nutr. 2014; 11: 21

12. Sobieszek M, Krupa M. Rola dietetyka w leczeniu jadłowstrętu psychicznego Polish Journal of Nutrition. 2016; 1: 55-60.

13. Pisarska-Krawczyk M, Jarząbek-Bielecka G. Zagadnienia interdyscyplinarne w ginekologii praktycznej. Wydawnictwo PWSZ. Kalisz. 2013.
14. Paszyńska E, SłopieńA， Dmitrzak-Weglarz M, Tyszkiewicz-Nwafor M, Rajewski A. Zaburzenia odżywiania - wyzwania diagnostyczne terapeutyczne z perspektywy lekarza stomatologa: XXVIII Konferencja Sekcji Psychiatrii Dzieci i Młodzieży “Zdrowie psychiczne a etapy rozwoju”. Poznań, 28-30 września. 2015

15. Jarząbek-Bielecka G: Seksuologia a etyka seksualna i problem dzieci wykorzystywanych seksualnie. Wydaw. Nauk. Akad. Med. im. Karola Marcinkowskiego. Poznań. 2009.

16. Imieliński K. Erotyzm. PZWL. Warszawa. 1973 